\title{
DRIFTING AWAY FROM ENGINEERING HUMANITY: TECHNICAL HUMANITY A MIRAGE
}

\author{
Hinal Vachhani \\ G.H . Patel College of engineering and technology \\ Vidhyanagar, Gujarat \\ India
}

\begin{abstract}
We all are a tiny part of the technical world. A world in which technical science has a victory over human science. Is profession reason behind so. Is critical thinking scrubbing humanitarian thoughts? Can we consider industrialization is the chief reason behind the shifting of engineering humanity? Are humans competing with humans or just a body with the brain? These brainstorming questions let us to think in a broader way. First of all it is crucial to comprehend what does it mean when we say engineering humanity. This article reflects the various edge of it. $A$ deeper drive in the topic will make the topic crystal clear.
\end{abstract}

Keywords: Technical humanity, engineering world, humanitarian approach, technodox, renaissance

\section{INTRODUCTION}

\section{Human science}

Engineering humanity a sky-touching topic that deals with the humanitarian approach in the engineering domain dealing with the limitless dimensions in the field of ethics and morals. We need to know the role of humanity in the engineering practices and engineering education.

Is humanity hallucination in the world of engineering? Is it turning technical? Are all these matters trapped only in pages of books?

It is at a stake in the professional world. Taking its last breath in terms and fighting from various issues of cruelness.

We engineers are the one who are very much in ascendant in public as well as corporate life far beyond their daily roles.

To answer the above questions when we think of humanity we come across various domains such as love, regards, sympathy, affinity, generosity, kindness, empathy and the list goes on. There is just the growth in population and not human we need to apprehend the reason behind it. It's time to turn over a new leaf. We need to develop a bold path for a sustainable, connected, healthy, creative and secure humanity. It's an alarming need to blend engineering with real education as a remedy that can serve the society and bring advances to the many challenges.

Technological renaissance started along with industrial revolution of $18^{\text {th }}$ century in England. Which led to the development of technically advanced generation and increasing human comforts. Moreover, journey from page to pager and from pager to screenager is so excited with novice technical adventure which are full of enthusiasm and curiosity which has tremendous power to attach human mind $100 \%$ in it. Means this technology has potential to take over each and every human mind. It can be said it is like a magnet that never allow to detach from it. Technology has change the way of perception towards every aspect of life, which may be full of creativity. Technology over powers the world of human accuracy. For instance, robots, mobiles, super computers.

The World of Automation

The precious gift given by the technology, which has even reduce human efforts and has given rise to life beyond our imagination. Furthermore, extreme level of Replication can be seen in the technosavy world. Simultaneously there is a buzzing need to know the other side the mountain which has equal potential to ruin the human. If the cultivation of automation can lead to socio emotional detachment. Which is again a threat to humanity.

There are various aspects in which human-computerinterfaces affect humanity and socialism. Technocrats contribute in the development of the new technologies and shaping the world while doing so they are serving the society at the same time they are destroying it above all pretending to be knowingly unknown. 


\section{MODERN DAY SCENERIO}
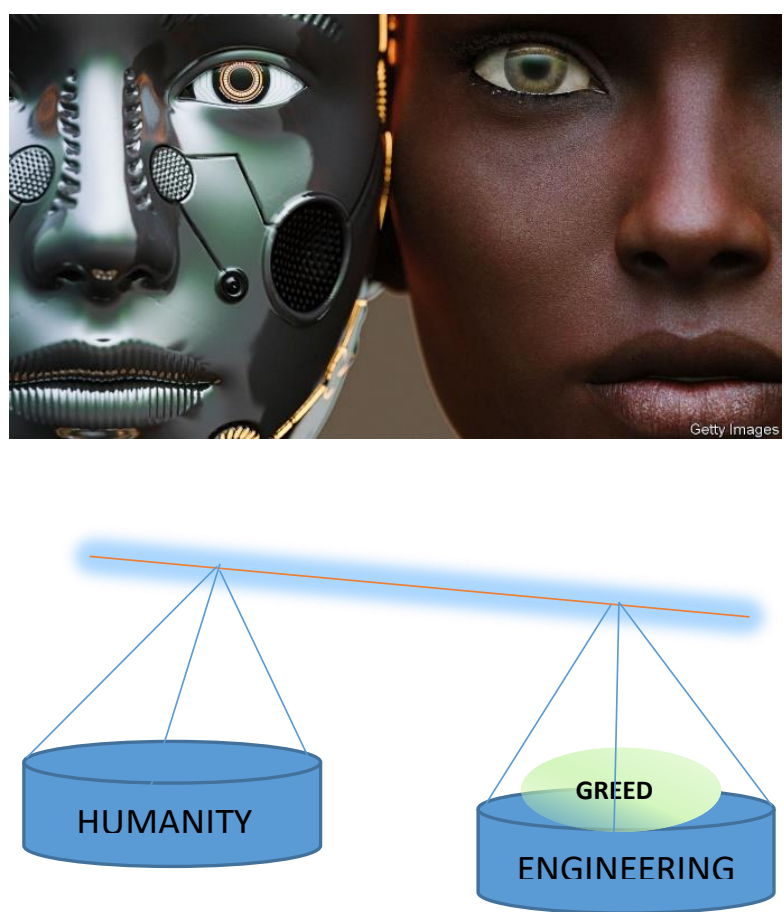

It commonly observed people are so engaged in their digital life that they are forgetting the real meaning of life. On 24th May 2019, a fire occurred at a commercial complex in Sarthana area of Surat in the Gujarat state of India where many children jumped from the building but no one helped them rather people chose to capture the event on camera. In the city of cloths, so-called Surat could no one stand holding a cloth to save the lives. Was it so hard? After evaluating the situation it was found that unethical engineering practice was also one of the reasons behind it. Also, many other reasons led to this. This incident very well explains the situation of humanity in today's era. What would you do if you were there?

The above case teaches so much. If engineering ethics and morals had followed then we could have saved those lives. Infact if people who were there had bit humanity could have saved many lives. We cannot change the end but can be aware. This was one of the eye opening incident. We need to develop comprehensive assessment program for engineering education for continuous improvement of engineering education with humanitarian principles and by inculcating values and teaching regarding objectives of life.

\section{Lack of value based education}

When we think of such situations, various questions pops into our head. One such prominent question is that what are the issues that generate the need of value based education. The above question is a vast domain in itself. What are the reasons for the same?

To answer the above matter
Which results into human greed, technically lunatic are one of the prime causes for the same? Still there are various hidden challenges for the same.

\section{BACKDROP}

Let us rewind the picture. Ancient Indian Education system was the best system in the world in every manner. Education doesn't mean four walls of classroom but go beyond it. Go to the nature, go to the society, which are the pioneer tutors for any learner where values, skills and individual maturity were by default product of the system where education was not only about gathering information but also cultivation of it which leads at last to the wisdom. In addition to this it was the system where horizon of science, religion and preserving culture was the dominating facets. For instance, Asharamshala education which focused on the need based education.

Death of humanity is felt at every moment and at every second. Is humanity a measurable quantity? Can we find its dimensions? It's easy to punish a criminal for its crime but what about a person with a lack of humanity and for the one who finds ways to duck out of his duties and responsibilities?

\section{Need based education?}

In the current scenario on the name of need based education hardly positive arena can be observed. Why is it so? Who is responsible? Whom should we blame and who will bring the change? Are we the significant part of it? But desired and active applicable output is not there because of numerous hidden and unhidden restrictions by the teacher, management, government, society, etc. In reality everyone wants to live in designed frame, which is comfort zone where advancement of anything is just a mirage? We need to have guts to break the ice of those so called hidden technodox whereTechnodox, here means technologically driven person.

\section{CURRENT CHALLENGES}

Is it possible to novice sunlight of morning with value based education? Is it possible to bring back techno toxic people in this range of humanity? Is only educator has the responsibility of this or society too? Is the current youth is really youth or big question mark on the name of head and heart fertility. If we are genuinely answering to the burning questions then there is a ray of hope that stops the drifting away of humanity.

\section{Are we equipped and competent?}

Self-assessment and genuine introspection may work like renaissance at an individual level to Have a civilized society where valley of virtues are blooming and bloom. We are living in the world where we are producing technologically illiterate people. They are money oriented mind set rather than human oriented. We need to start embarking journey towards contributorship.

1) Socio-Emotional detachment 


\section{International Journal of Engineering Applied Sciences and Technology, 2020 \\ Vol. 4, Issue 12, ISSN No. 2455-2143, Pages 215-217 \\ Published Online April 2020 in IJEAST (http://www.ijeast.com)}

For a breath of fresh air, Why not every individual consider its prime duty to guide humankind towards the right path. New blood needs to blaze a trail to break new ground. Engineers can pave way for it. Let us choose to tackle and fight back on humanity at the workplace rather than wriggling out of the situation.

\section{CONCLUSION}

Engineers being one who creates the problems and one who solves it. Comprehending the topic by understanding the need of this era. It would add more value if we become an engineer for humanity rather than engineering with humanity. Let us promote engineering with the heart rather than engineering with the brain because the world needs more human.

Humanities teaches engineering professionals that with all the answers there are still problems for which there can be no possible solutions. But the destination is always to find the answers. Humanity reminds one that there are some issues that can never be addressed by technical approach, one needs to apply his heart into it to solve it, the brain will not work there.

Engineering ethics is small piece of cake from the whole that is humanity. We talk about morals and ethics which should one of the core concepts in engineering practices.

\section{ACKNOWLEDGMENT}

This research article would not have been possible without the support of Dr. Amita Patel and for her constant supervision. Deep gratitude to the school teachers and my family along with some of my friends who gave me confidence and strength.

\section{REFERENCES}

[1] Grasso D., Martinelli D. (2010) Holistic Engineering. In: Grasso D., Burkins M.B. (eds) Holistic Engineering Education. Springer, New York, NY, https://doi.org/10.1007/978-1-44191393-7_2

[2] Stieb, J.A.(2007) On "Bettering Humanity" in Science and Engineering Education. SCI ENG ETHICS 13, 265-273 https://doi.org/10.1007/s11948-007-9014-9

[3] R. R. Ernst,(2006) "Science, engineering, and humanity," in IEEE Engineering in Medicine and Biology Magazine, vol. 25, no. 3, pp. 18-19.

[4] Gunn, A., \& Vesilind, P. (2003). Hold Paramount; The Engineer's Responsibility to Society. Pacific Grove, California: Brooks/Cole-Thomson.

[5] Fátima Monteiro, Carlinda Leite \& Cristina Rocha (2019) From the dominant engineering education perspective to the aim of promoting service to humanity and the common good: the importance of rethinking engineering education, European Journal of Engineering Education,44:4,504518, DOI: $10.1080 / 03043797.2$ $\underline{018.1435630}$

[6] ) Tallis R.C., Litt D. (2008) Enhancing Humanity. In: Madhavan G., Oakley B., Kun L. (eds) Career Development in Bioengineering and Biotechnology. Series in Biomedical Engineering. Springer, New York, NY, https://doi.org/10.1007/978-0-387-76495-5_61

[7] Mitroff I.I. (2019) How Technology Both Enhances and Diminishes Our Humanity. In: Technology Run Amok. Palgrave Macmillan, Cham, https://doi.org/10.1007/978-3-319-957418_9

[8] Bostrom N. (2009) The Future of Humanity. In: Olsen J.K.B., Selinger E., Riis S. (eds) New Waves in Philosophy of Technology. New Waves in Philosophy. Palgrave Macmillan, London, https://doi.org/10.1057/9780230227279_10

[9] Osterle H. (2020) Life Engineering as a Discipline. In: Life Engineering. Springer, Cham, https://doi.org/10.1007/978-3-030-31482-8_7

[10] Anālayo, B. Ancient Indian Education and Mindfulness. Mindfulness 10, 964-969 (2019). https://doi.org/10.1007/s12671-019-01145-3

[11] Cristian H.Birzer \& Jaimee Hamilton (2019) Humanitarian engineering education fieldwork and the risk of doing more harm than good, Australasian Journal of Engineering Education, 24:2,5160, DOI: 10.1080/22054952.201 $\underline{9.1693123}$

[12]Chimirri N.A., Schraube E. (2019) Rethinking Psychology of Technology for Future Society: Exploring Subjectivity from Within More-ThanHuman Everyday Life. In: O'Doherty K., Osbeck L., Schraube E., Yen J. (eds) Psychological Studies of Science and Technology. Palgrave Studies in the Theory and History of Psychology. Palgrave Macmillan, Cham, https://doi.org/10.1007/978-3-030-25308-0_3 